\title{
FIRST PLACE
}

\author{
Grief
}

He lies beside her. She's under the sheets, she's thinking about her mother, she's trying to recall the details, but she can't seem to start. She doesn't trust what she remembers; she thinks it all sounds too maudlin, too melodramatic. She looks at him, twists her face. She opens her fingers and runs the tips over his eyes. She traces a line down each cheek.

She's not crying, she can't weep. She is just sitting in the bed, holding the face of this man. She says, I just don't want to say it wrong. She says she's trying to remember, but it feels like she can't recall any of it, and of course that's impossible-how could anyone forget something so terrible.

It's difficult, this trying to place something. The mind muddles with age; after a thousand million different rememberings of something, the original thing has disappeared. She's not sure, even now, how she felt. Really she felt in a million different ways. And each time she remembered them, she felt a new way again.

So really, she thinks, how can she place anything? How can she make sense of this serpent, this changing, malleable thing? There must have been a time, there almost always is, a time Before. There must have been a moment where this thing did not clutter her life.

But now her home is After, and everything is touched by it.

This much the girl knows with certainty: The kitchen was full of food and medicine. Instant oatmeal, brown rice, cake mix. Honey, canned tomatoes, fresh oranges, soy sauce, vitamins, aspirin, danazol. Avocados, peaches in season, some grapefruits, three kinds of antiemetics, syringes, Soma, prednisone. White sugar, brown sugar, blue pills, yellow pills, gauze (the chemo was internal, and left a wound). Three frying pans, a wok, half-a-dozen eggs, Valium.

After a period of time, we think a wound has healed. We say that time has fixed us and we mean it. Still there is a moment, a still and silent moment, when something shines aware, and we smell fear again, and it is our own.

She died when the girl was eleven. And since then there has been no room for ignorance.

The woman didn't want to be sick. It seems like this is an important point to make clear. There was one night when she got angry, she screamed. It seemed all the more horrific at the time, because at first the woman was resolutely unafraid, she looked the possibility in the eye and dared it.

But one night, it was a spring night, the girl and the woman were in the bathroom. The woman was drawing a bath for the girl, and the windows were open, and outside crickets were humming and the smell of night-blooming flowers was sifting toward the screen. The water was colder than expected, and when the girl went to kneel in it she sprang back from the cold and sprayed the woman. The woman's gauze shirt was all wet and you could see inside, see that her chest was flatter than the girl's, see the soft pink moons of scars.

That night, the night of the scream, it wasn't because of the scars at all. It was the jasmine, and the crickets, and the girl, and then the woman, throwing towels, her shirt soaked, the water running in the bathtub. The woman's eyes were lined with red, and she tensed up, each muscle line demarcated like rock, and she yelled.

For the girl the sound of this yell has never left her. There was something ancient in it. It came from so deep it seemed as if it must have originated beneath the floorboards, underneath the bedrock. It was the origin of earthquakes.

And still it wasn't pain. It was anger. It was a growl. It was the howling sound of a lonely wolf, the gutteral grunt of a dying buffalo. It was something deep, something choked and cluttered.

The word the woman screamed was, No.

But the girl, this girl who is older now, who strokes the face of this man, she worries. She does not trust what she remembers. She thinks this too could be a lie. Really, the girl wants to tell you, she is not sure if this is true. She remembers the bathroom, and the cold water, and her mother screaming, but she can't remember the context, can't be sure about it. The form has become indefinite to her. She can't trust it. So now she feels like she's just lied. She has lied. She looks at the story she's got in her head and suddenly it is all wrong. She wants to do something, to do anything, but the past has slipped away from her fingers.

She's the only one who knows the color of the skin on the woman's inner wrist.

Before all this, in the time the girl only thinks of as Before, they used to eat onion and avocado sandwiches for lunch and run to the park and swing. They would crawl in the trees; sometimes the woman would climb high and hide. In winter they would go to the ice rink and twirl each other around. And then the man would come, and he'd say, Look at my girls, and they'd all smile. There are more things the girl remembers: her smell, the way her voice got gritty towards the end, the blue bathrobe with cigarette 
burns, what her hands looked like, that she always burned the pancakes, that she loved Joan Baez, that she didn't believe in makeup, hair dye, or dresses.

But the making of a memory isn't really a conscious act. It's a surprise. You go to bed thinking about something, and then you might forget about it for a while, and then one morning you wake up and remember it again. But it's completely different now, something very different than what you once thought it was. And you feel as if you might never be able to remember again, how it was once, how it was then.

The woman was asleep. The girl had gone into the bedroom, the man had left to go buy dinner, the woman was sleeping. Beside her, fallen to the floor, was a square of black silk. Usually it covered her head, kept it warm, the hair was going and so she had to keep something there. Asleep the woman looked small and vaguely elfin.

The girl had never seen the woman as something living before. She was no longer some strange and powerful goddess. She was like a baby, a child; she was sleeping. The girl was afraid.

But a life isn't so simple. All it is, really, from the time one gets up to the time one goes to bed, and even then, nothing more than a war.

After a while the woman was sicker. She had gotten thin. She wore a blue bathrobe all the time like a prayer shawl. She sat at the table for hours upon hours. She talked to the girl in lists. She wanted to be sure that the girl would never be unaware. She told the girl that there were squirrels that could fly, and pieces of ice frozen solid for millions of years, and trees whose trunks were wider than cars. She told the girl that there were some people who spoke a language that couldn't be written down. That somewhere, in some far southern place, there were pictures in the grass that could only be seen from the air. That part of Florida was really from Africa, and California was slowly floating north.

There was some kind of promise in the list, some gauzy suggestion the girl didn't quite notice at the time. Now when she remembers the list, she imagines the woman speaking in a strong and powerful voice, saying something wise. Speaking with great wisdom, seeing beyond. Saying, It doesn't matter. Saying, Don't be afraid. Life is a great spread of possibility. Even now I will not forsake it.

The woman sat on the couch underneath the glass window looking out in the backyard. Outside birds in the apricot trees made the leaves shake, and there must have been something going on, because the tree shook back and forth with vehemence, but the sound was hidden. There was a great ruckus but no one could tell what it was.

The girl came into the living room and asked the woman to come, and the woman said she would. Then the girl left, but the woman did not appear. The girl called to the woman, Are you coming?, and the woman yelled back something that sounded like yes. It was an affirmation.

But still the woman did not come. The girl tiptoed into the living room again, just to check. The woman still sat in the couch, staring out the window. The jays outside swooped, there was a great rush of movement-but still no sound. Eventually a man came into the room - the girl cannot remember if it was her father-and walked up to the woman. The man knelt down, and the woman put her arms around his neck, and they stood still for a long while. And then the man said, Hold tight, and slowly pulled the woman up until she stood.

This is a way of introducing that towards the end the woman couldn't walk.

Sometimes the girl and the woman would make lists together. On one list would be happy things: birthdays, apricots form the tree, ice cream sundaes and lollipops.

The other list, the list they only thought, would be sad things: candles without flames, dammed rivers, trees frozen and bare in winter. And of course this thing that was happening. They were always so strong about it. They would not cry. They looked at this thing in the face and tried to hold ground.

They paused for a while, and then went back to the happy list.

Once, before the woman left for the hospital, before she could not stand, while the cure was still a promise, they all went to the sea. It must have been August, the waves were dark; in California you tell the seasons by the color of the water. They were watching the sunset. The sky was painted in bright bird-colors.

The sun was strong, it was beating down. The woman was wearing her wig, she only wore the turbans in the house. But the wig was hot, and itched. So the woman pulled it off. There were a few wisps of dark black hair, but mostly just skin. It was like a baby's head.

At the time, the girl is sad to remember, she felt mortified. Young boys collecting shells pointed at the bald woman and laughed. The girl felt shame.

Now the girl thinks of the woman, of that day at the beach, with a feeling one might call pride. She thinks of the woman, the sunlight glinting off her head. In a way at that moment they all knew what was to happen. But the woman took off her wig, she stood in the sun. She knew death was coming; she was strong and stood her ground. She was Joan of Arc, she would not waver. She stood for the journey with eyes open. 
The thing about the day at the sea, with the waves breaking, and the woman and the girl and the man all sitting on the sand, which felt like sugar really, was that everything seemed, at that moment, to be all right. The ocean was full, it moved. Gulls broke the surface of the water, the pale orange beaks diving down below the surface, splitting it. The world was right.

See, the woman said. See, the world tuns and here we are all here, privileged to see it.

Later, they opened her up and couldn't do anything. They closed her up. They said, It's just a matter of time.

It occurs to the girl now, in this day, that the beauty of that day by the sea is that everything felt home. It occurs to her now that there is nothing sadder than the water that does not reach its destination. The Colorado dying out in marshy fields before it runs home to the ocean in Mexico. The Amazon, tributary after tributary hoping for a shorter path to the sea. An inland ocean slowly drying up, choked on its own salinity.

A heart of grief.

The cure is not a cure. It hangs by a tiny thread. It is not a cure, a stopping, but rather just a line in time. A moment when what they were doing was waiting for what would come next. A still and silent space, a large hole in the only one possibility.

These are things the girl doesn't remember: how it felt to kiss the woman, what her hair felt like, what she dreamt, her favorite movie, why she loved California, how old she was when she had her first kiss, the way her eyes looked when she was proud, what kind of day it was when she first found out.

Then one day the girl came home from school and the woman wasn't there. The woman had been moved to the hospital. The girl spoke to the woman on the phone. Her mother's voice sounded clear and strong. She promised to come home soon.

It was only later that someone, an aunt maybe, told the girl this: When the girl was done talking, the woman could not speak. She had saved up all her strength for her child, and then it was gone.

The hospital room is white. In the bed a bald woman is sleeping, wrapped in sheets, strange tubes going to her nose and her mouth, both arms, one on her chest, one between her legs. She is drifting in the dull stupor of morphine.

In one corner is an older woman. This woman is the child's grandmother, only her hair is down; it matches the room, ghostly clean, all white and silver. The girl walks to the bed, slowly. The woman in bed rolls over and looks at the girl, through the girl, she smiles. She looks at the girl and a strange smile works its way over her features. It's a child's smile; it's the smile of someone who just got ice cream. It's unthinking, unthought, an innocent smile. She giggles.

There's one thing that's stayed with the girl, the strangeness of that smile. The smile is so strange. The eyes are not in it. The woman is no longer beautiful, really; that's what's wrong. She used to be gorgeous, they all spoke about her as the most beautiful, precious thing. But she's not, not anymore. Now, instead, the word for her is ravaged.

They are in that white room, that clean room, the hospital. The woman is looking at the girl, still with that same strange face. The girl touches the woman's hand. Here, the girl says. She's made a book, in school. It's a sixth grade book: it's got cardboard for a cover and poems inside.

The giggling woman takes the book, turns the pages, slowly, one after the other. At each page she stops, and sighs, ooohs and ahhs, and laughs and points. She looks up at the girl and nods. And says, How beautiful.

The girl moves close to the bed. See, everything is normal. Everything will be fine. But when she bends down to see where the woman is pointing, she notices that the book is upside down.

See, the woman says, See how beautiful.

It's not really a statement. It's somewhere between a question and an order. A command the girl will carry with her the rest of her life. It's a prescription, the only one that might work.

How beautiful, the woman says.

The girl is confused. She doesn't understand. But somewhere deep inside her instinct takes over, the body's processes give themselves up to unthinking preservation. Yes Mommy, the girl says. Yes, it's beautiful.

In that moment everything is gone. It's all been stolen from her, everything has. It's been taken. They've all been robbed. No one has gotten her due, not at all.

They all look at each other. There was some glimpse that the mother made. Fleeting behind her eyes, fighting battles to be shown, was a slightness of recognition. There was something there. There was something trapped inside.

It's this moment, that moment where the girl and the woman were unknown to each other, were pulled apart, were fighting so hard to reach a place that had already disappeared, that the girl always thinks of. This is her talisman, her leitmotif, the moment that resonates to her the most unfair.

This is the moment that they should have looked back on all their days as the space in time when they dropped their filial bonds and became friends, too, to each other.

The last days are always the hardest days. You would think they would be easy: Everyone knows what's to happen, it's not a 
surprise any longer, it's just a matter of waiting. Death is coming. He's not waiting for you to ease into it. Really he could care less. Somewhere low on the horizon his shadow slips across the deep dark earth, slowly, patiently.

The way it happened was simple. They had all just come home. The phone rang, and the father went to the phone, and it seemed as if he were talking loud but really he was whispering. In any case no one could understand a world of what he was saying; it was as if he had always been speaking something else, a language no one else had ever known.

The girl went into the living room. She did not want to see. She was in the dark by the couch for a long long time, watching the leaves waltz in the wind outside. Then her uncle was there. The uncle looked at the girl and said, "She's gone." And then he didn't say anything else. He put his arms around the girl, and she stood very still for a very long time, but she did not weep.

The myth in the family is that the woman died without pain. The myth in the family is one of sweet death, precious peace. The myth in the family is that the woman was already gone, that it was just a matter of time. That the good always go too soon.

As if there wasn't a whole life there, a series of splendid, webbed connections. As if the woman wasn't strong and beautiful, didn't move like a fairy in the eyes of others. As if death really were easy, really were wanted.

Now the girl likes to think, it is easiest if she does like this: As if the woman belonged not to her but to the world.

It wasn't the cancer in her breast that killed her. And it wasn't the cancer they found later, in her ovaries, that killed her. And it wasn't the cancer spread to her lungs, or the cancer in her spleen, or the cancer throughout her bones and her spinal cord. Instead, what killed her, was the enemy in her mind, the thousands upon thousands of tiny cancers that radiation had wrought, a galaxy of bitter, tragic stars.

The girl doesn't know, no one has ever told her, what the woman's last words were. This seems to the girl to be a great breach. She is sure the woman must have spoken. The woman was the type to make pronouncements; she believed in the power of language. And yet, there are no words. No one has ever said to the girl, the woman said " $\mathrm{X}$ " or the woman said "Y," so the only thing the girl has is her imagination.

There was never really a feeling of despair until after, that much the girl remembers. Along the way, up till that last irrevocable point, there was always hope.

The girl is embarrassed to tell you, she has not been to the grave in a long time. She tries to visit each time she is home. She hates thinking that her life has moved her so far away from this grassy meadow, and the flat, hidden, dusty marble of the stone.

The last time she was there was in summer. In the distance the hills of California circled like sentries, and there was a momentary feeling of protectedness. The girl sat there, next to the stone, for a very long time. And it was sad, really, so very sad, the way she looked down at the ground. With an open heart, a bleeding wound, tearful eyes, and a secret, silent astonishment, that somehow her life had moved, and that somehow, in a still and silent way, she and this woman were strangers.

In life lots of things happen, all the time. Death waits for no one. People grow, they age, they die, sometimes they don't age really at all, they just die. And what happens then is forgetting. Forgetting what was there before, what was obvious all along, the clues that were anticipating the event. Forgetting the event itself, and all the little minor events that seemed inconsequential at the time, but now loom on the horizon like a setting sun, an inescapable glare to the eye.

The way it's supposed to be, the way it was in the past, women always kept a lot of things. They kept their children's first shoes, their favorite toys, later their homework and essays, the awards given each end of the term. They kept photos from every party, scraps of material from favorite dresses. They kept pictures from their own past, love letters, pressed flowers from weddings, photos from a time previous, known only to themselves, a world their children had never seen.

But now it is a girl who is left, a child. So she has become the collector. In her closet at home she stores a suit, long out of style, that was never hers to begin with. There is a box of notecards, clues for a thesis that is missing and has never been read. There is a photograph of a woman in a fancy dress. The woman, really, is like a ghost of the girl; you can see how they're the same. The woman is posing for the camera, and there's another photo with five or six or seven other women, wearing pill-box hats, holding on to a cable car, looking vaguely inspired. 